\title{
THE IMPACT OF AUXILIARY RECRUITMENT ON PROVINCIAL SOCIETIES FROM AUGUSTUS TO CARACALLA \\ By I.P. HAYNES
}

Rome's ability to exploit provincial manpower in defence of her Empire has long fascinated scholars, just as it clearly appealed to ancient observers, but there have been few attempts to assess the impact that maintaining the auxilia actually had upon provincial cultures. Recognising the importance of this theme, Professor Millar has argued 'the recruitment of non-citizens into the auxiliaries and their discharge as citizens was one factor in the Romanization of the provinces'.' It is one thing to argue for such an impact, however, and quite another to attempt to quantify it in any way. The issue of quantification is, of course, a perennial problem when discussing what is commonly, though not always helpfully, termed Romanization. Assessing how far changes wrought by Roman imperialism actually reached can be profoundly difficult. When looking at the relationships that existed between military and civilian communities the problem is exacerbated by the diverse and changing character of the participants. Between the reigns of Augustus and Caracalla, the Empire, provincial societies and the army itself changed in many ways, not all of which are well understood.

The difficulty of broad generalisations becomes apparent when approximate figures for the number of men serving in the alae and cohortes are set against

Abbreviations

AE L'année épigraphique

BGU Berliner griechische Urkunden

CIL Corpus Inscriptionum Latinarum

CPL R. Cavenaile (ed.), Corpus Papyrorum Latinarum (Wiesbaden 1958)

FIRA Fontes Iuris Romani Antejustiniani (2 ${ }^{\text {nd }}$ ed 1940-3)

ILS H. Dessau (ed.), Inscriptiones Latinae Selectae (Berlin 1892-1916)

P.Lond. F. G. Kenyon / H. I. Bell, (eds.), Greek papyri in the British Museum (London 1893-)

P.Oxy. $\quad$ B. P. Grenfell / A. S. Hunt/H. I. Bell et.al. (eds.), The Oxyrhynchus Papyri (London 1898-)

PSI G. Vitelli / M. Norsa et.al. (eds.), Papiri Greci e Latini (Pubblicanzioni della Societa Italiana per la riceria dei papiri grec e latini in Egitto) (Florence 1912-)

RIB R. G. Collingwood / R. P. Wright, The Roman Inscriptions of Britain. Vol I. Inscriptions on Stone (Oxford 1965)

Wadd. Waddington, Inscriptions grecques et latines de la Syrie

${ }^{1}$ F. Millar, The Roman Empire and its Neighbours (London 1981, 2nd ed.), 5. 
our best estimates for the Empire's population. During the first two centuries $\mathrm{AD}$ the regular auxilia probably never grew to much more than 215,000 men. To maintain a force of this size in peacetime would, I estimate, require about 10,500 recruits annually. Such a number would be necessary to replace those men who died in service and the approximately 6,500 soldiers honourably discharged each year.2 Even if members of soldiers' families are included amongst those somehow directly affected by the pattern of recruitment and discharge, and even if the resulting calculations are considered across a generation, the total number of individuals involved is small when set against the lowest commonly accepted estimate for the Empire's population, 50 million. Though these figures need to be viewed alongside those for the number of men enrolled into the legions, sustaining such an auxiliary force would not appear to pose a major problem for the Empire as a whole. Nor would the number of veterans ever constitute more than a very small proportion of the total population. Yet it is vital to recall that the burdens and opportunities that arose from the existence of the auxilia did not fall evenly across the Roman world. Understanding regional variation therefore becomes crucial to understanding the impact of maintaining the auxilia on provincial societies. This paper therefore seeks to combine a general overview of both recruitment and discharge of auxiliary soldiers with specific regional case studies.

\section{Recruitment}

Meaningful study of recruitment patterns must encompass both the formation of new units and the ongoing supply of soldiers to existing ones. The first is fairly straightforward, the latter rather less so.

In a typically concise and insightful summary, Le Bohec, drawing on updated versions of Cheesman's original tables, observes marked regional variation in the formation of the Empire's 383 known auxiliary units. ${ }^{3}$ More than three

\footnotetext{
${ }^{2}$ I base this estimate on the calculations summarized and developed by R. Alston, Soldier and society in Roman Egypt (London 1995), 46. He considers the number of men necessary to maintain a force of 5000 men. Taking an average of his figures it appears that such a force would discharge about 152 veterans per annum. Approximately 247 recruits annually would be required to keep the force at full strength. These figures constitute rough averages. It is clear, however, that in those years when units were on campaign there would be greater need to enlist recruits as well as less inclination to discharge them.

${ }^{3}$ Y. Le Bohec, The Imperial Roman Army (London 1994), 96.
} 
quarters of these regiments (78.5\%) came from Europe, indeed over half (56\%) came from western Europe alone. This is in stark contrast with Asia, which provided $15 \%$, and Africa, source of the remaining $6.5 \%$. Inequalities within this arrangement are more striking still when considered at the provincial level, almost a third of all alae and cohortes were raised in just two provinces, Tarraconensis and Lugdunensis, before the end of the Flavian period. ${ }^{4}$ The implications of this imbalance would reward further investigation within the broader context of each province's history. Within provinces, as the case studies below demonstrate, there was still further variation as some communities supplied far more units than others.

More than mere numbers determined the impact of this process upon provincial societies however, and the way in which regiments were raised was also significant. We may reasonably surmise that there were several ways, or more correctly, several combinations of ways by which this took place under the Empire. These were:

\section{Enrolment of war bands that ultimately become regularised. ${ }^{5}$}

2. Incorporation of regular forces formerly in the service of client rulers. ${ }^{6}$

3. Conversion of militia into regular units. ${ }^{7}$

4. Dilectus from populations already long incorporated within the Empire. ${ }^{8}$

5. Dilectus from populations following their military defeat by Rome.?

This is a very simple outline and the categories are by no means mutually exclusive, but they do give us some sense of the varying levels and forms of impact that recruitment would have had on provincial societies. The local demographic impact of incorporating the regular forces of former client kings

${ }^{4}$ G. L. Cheesman, The Auxilia of the Roman Imperial Army (Oxford 1914), 173-4, 183-5.

${ }^{5}$ The ala Atectorigiana is the most frequently discussed example of this phenomenon. The process is discussed by A von. Domaszewski, Die Rangordnung des römischen Heeres (Bonn 1907), 122-3; Cheesman 1914, op.cit. (n.4), 24-5 who would nevertheless like more evidence; and E. Birley, 'Alae named after their commanders', Ancient Society 9 (1978), 265-6.

${ }^{6}$ See D. L. Kennedy, 'The military contribution of Syria to the Roman Imperial Army', in D. H. French/C. S. Lightfoot (eds.), The Eastern Frontier of the Roman Empire (Oxford 1989), 238 for this device.

${ }^{7}$ See for example Cheesman 1914, op.cit. (n.4), 20 and P. A. Holder, The Auxilia from Augustus to Trajan (Oxford 1980), 110, 142.

${ }^{8}$ There are, of course, a great many instances of units raised in this way. Perhaps the most obvious examples are the cohortes voluntariorum.

${ }^{9}$ There are several likely candidates for units formed in such circumstances, at least some Dacian units, for example, were formed in the immediate aftermath of Trajan's conquests north of the Danube. Other probable examples of this strategy are discussed in more detail below. 
would be far less disruptive than, for example, a dilectus designed to remove manpower inclined to revolt. Some of the men enrolled into newly formed units were able to stay close to their homes, but for others enlistment meant service abroad and brought greater disruption to their lives. Such an eventuality was clearly feared by the tribes involved in the Thracian revolt. ${ }^{10}$ Across the Empire, reactions to military service must have varied, in some instances, the transformation of war bands into warriors for Rome would be welcomed; in others conscription may have had a strongly punitive aspect. Even amongst peoples friendly to Rome, that recruitment of auxiliary soldiers - the conduct of the dilectus - could be brutal and traumatic. Tacitus's vivid account of the luckless Usipi demonstrates this last point admirably."

Literary descriptions of disastrous dilectus illustrate the problems of conscription and the extent to which they could disrupt the wider community. Tacitus repeatedly links the dilectus to the destruction of family ties, for example, and there is some support for this association in the epigraphic sources. ${ }^{12}$ Yet it is still extremely difficult to assess how common or indeed how rare the practice was. This represents a grave problem for any scholar studying the impact of recruitment on local populations.

Both volunteers and conscripts served in the ranks of auxiliary units throughout this period, but in what proportions it is currently impossible to say. There is a general consensus amongst scholars that the proportion of soldiers in the army who were volunteers grew until they constituted the majority at the end of the second century, but this view may reflect the nature of our sources more than the ancient reality. ${ }^{13}$ One point that is well worth emphasising, however, is that a third group of soldiers existed within the ranks. These men were the vicarii (replacements), mentioned in the correspondence between Trajan and Pliny. ${ }^{14}$ Their existence reminds us that wealthier subjects were able to avoid conscription if they could pay someone to serve on their behalf. Clearly not all

\footnotetext{
${ }^{10}$ Tacitus, Annals 4.47 .

11 Tacitus, Agricola 28.

${ }^{12}$ See Agricola 15.3 and 31.1 and Histories 14.4.3.

${ }^{13}$ The key ancient source for this is Arrius Menander, who wrote under either Severus or Caracalla. He contrasted his own day, when most of the soldiers were volunteers, with earlier times when many sought to avoid the dilectus (Dig. 49.10.10-12). This rosy picture is qualified by evidence showing that it was still necessary to confirm exemptions from conscription under Commodus (Dig 27.1.6.8) and that there was money to be made in AD 185 from hunting down draft dodgers (P. Lond. 2.173).

${ }^{14}$ Plinius Minor, Epistulae 10.29.
} 
social groups were equally affected by the impact of imperial recruiting practices.

How did the ongoing need to supply units with fresh drafts of recruits affect the provinces? Scholars have historically argued that most units, excepting specialist archer regiments from the East, increasingly followed a practice of local recruitment. ${ }^{15}$ This view has its origins in the work of Mommsen well over a century ago. ${ }^{16}$ When he formulated this model, Mommsen relied heavily on evidence from North Africa, but evidence from other provinces discovered since indicates that different practice existed elsewhere. ${ }^{17}$ Taken together, our evidence suggests that the term local is not a particularly helpful one: it is more useful to speak of recruitment from the nearest available source. Such a source need not be local at all, but could easily involve drafts from local provinces. Fort garrisons with large and well-established vici may well have been able to recruit a handful of men annually, but by no means all auxiliary regiments were so fortunate. Even for regiments accustomed to draw recruits from their immediate vicinity, there would certainly be occasions when far larger numbers of men were required than the local population could provide. Regiments approaching their 25th and 50th anniversaries would, for example, discharge a markedly higher proportion of their soldiers than usual. Furthermore, units preparing for campaign would often require significant reinforcement. Again, this would most probably have required the recruitment of men from further afield. As a result, from at least the late first century soldiers in auxiliary units commonly served alongside men from different background. This phenomenon is clearly attested in an inscription from the Adamklissi Altar. An African, a Norican, two Britons, a Raetian, three Spaniards and twelve Gauls were all found at the same time within the ranks of one unknown auxiliary unit. ${ }^{18}$ The mixing of tribes and nationalities, a scenario once fiercely resisted by native communities, had clearly become commonplace.

It is interesting to note that the most frequently cited papyrological evidence for drafting procedures records a party of 126 men brought all the way from Asia

\footnotetext{
${ }^{15}$ For an important critique of the conventional wisdom on recruiting patterns in eastern units see D. L. Kennedy, The auxilia and numeri raised in the Roman province of Syria (Unpublished D.Phil thesis Oxford 1980).

${ }^{16} \mathrm{~T}$. Mommsen, 'Die Conscriptionsordnung der römischen Kaiserzeit', Hermes 19 (1884), 1-79.

${ }^{17}$ See R. P. Saller and B. D. Shaw, 'Tombstones and Roman family relations in the Principate: Civilians, soldiers and slaves', Journal of Roman Studies 74 (1984), 142-5.

${ }^{18}$ CIL III 14214.
} 
to reinforce a cohort in Egypt in $\mathrm{AD} 117 .{ }^{19}$ How representative this document is of practice across the Empire is impossible to say, but it is entirely feasible that drafts to many regiments were brought in from a considerable distance. That such a relatively large number of recruits came from so far raises questions as to how the supply of men was spread across the civilian population. It is clear that officially at least the most senior figures in a province were involved in the supply of even relatively small numbers of recruits. In a papyrus of $\mathrm{AD} 103$, for example, the Prefect of Egypt writes directly to the commander of cohors III Ituraeorum, ordering him to enter six men, whose details he also gives, on the regimental rolls. ${ }^{20}$ It might be tempting to imagine that with such senior figures involved a balanced overview was maintained which ensured that the provision of troops fell evenly across provincial territories. There is, however, no evidence to prove that this was the case and certainly some to suggest that a disproportionately high number of recruits did come from areas closer to where regiments were based. Furthermore, without detailed demographic evidence for each region it is hard to assess how much an even distribution really mattered. In certain areas the supply of volunteers and surplus labour might have been sufficient for the recruiting officers to meet their quotas without recourse to the unpopular device of conscription. Where conscription was necessary it would not normally be in the interests of provincial government to denude a particular area of manpower to the detriment of local economies, but this did not mean that officials had to be even handed in their treatment of different communities. The Roman government did not have to be fair, and quite probably would not have concerned itself with the concept, but it would in so far as it could seek a balance between the needs of the army and the needs of local infrastructure. In times of need, however, that balance could easily be overturned in the army's favour.

Le Bohec has argued that it is possible to identify a change in the social composition of the alae and cohortes throughout this period. ${ }^{21}$ Drawing largely upon onomastic evidence, he argues that during the Julio-Claudian period auxiliary soldiers were generally peregrini. A change then becomes evident between Vespasian and Hadrian as citizens begin to join the auxilia in some numbers. From Hadrian to c.170, under his model, citizens and peregrini are almost equally represented in the ranks until finally, in the period 170-210 the

\footnotetext{
${ }^{19}$ PSI 9.1063, the regiment concerned is cohors I Lusitanorum.

${ }^{20}$ P. Oxy. VII 1022 (= CPL III).

${ }^{21}$ Le Bohec 1994, op.cit. (n.3), 98.
} 
latter become relatively scarce. The argument seems plausible enough and if correct it would have some important consequences for any study of the impact of recruitment. It would also be entirely compatible with the growth of military families in which sons follow their fathers into the army. Yet caution is necessary: all the recruits in the above mentioned Prefect of Egypt's letter have the tria nomina, none have Egyptian names. It would seem highly unlikely, though not entirely beyond the realms of possibility, that all of these men were citizens. A more likely possibility is that at least some of them adopted Roman names on enlistment, a practice attested elsewhere.

Two case studies illuminate the range of impact auxiliary recruitment could have upon local communities. The first is the familiar example of the Batavi, the second, from across the Empire, the much less intensively discussed Ituraeans. Both peoples are characterised in the ancient sources as warlike, a quality widely admired amongst the former and lamented amongst the latter. For in the Batavi it is transformed into an instrument of Roman imperialism, while amongst the Syrians it manifested itself as an impediment to the pax Romana. Both peoples supplied troops to the Roman army in large numbers, but I will argue that in one case this served to perpetuate a martial ethos and in one to suppress it, in one case to stunt the emergence of urban government and in another to facilitate it.

\section{Recruitment amongst the Batavians}

The very origins of the Batavi reflect Rome's genius for social manipulation. Their community originated as a group of Chatti sent to the Dutch River Area under Octavian as part of imperial plans to bring the region under control. Their military significance for Rome grew thereafter. Contingents of Batavi most probably fought under Drusus and certainly served under Germanicus. ${ }^{22}$ Operating at first as tribal bands, they were organised into regular auxiliary units by the time the Romans invaded Britain. ${ }^{23}$ Their special status, which allowed them to serve under their own leaders and maintained the Batavian

\footnotetext{
${ }^{22}$ For service under Drusus see W. J. H. Willems, 'Romans and Batavians: regional study in the Dutch eastern river area, II', Berichten van de Rijksdienst voor Oudheidkundig Bodemonderzoek 32 (1984), 227. Under Germanicus see Tacitus, Annals 2.8; 2.11.

${ }^{23}$ G. Alföldy, Die Hilfstruppen der römischen Provinz Germania Inferior (Düsseldorf 1968), 45-8.
} 
composition of their units, survived the Civilis revolt and continued until into the second century. ${ }^{24}$

Historical and archaeological evidence indicates that the continuous supply of troops for these units and the ongoing military engagement of the elites had a significant impact on the Batavian community. This may be approached through studies of the evolution of the local economy, the demographic profile of the society and the centrality of what Nico Roymans defines as martiality. ${ }^{25}$

Rome's military demands upon the Batavi appear to have influenced the tribe's subsistence strategies. Willems observes that, with the exception of one brief period, pollen evidence from Kops Plateau from the late pre-Roman iron age through the Julio-Claudian period is consistent with cattle grazing and not settled cultivation. ${ }^{26}$ This, he notes, is entirely in keeping with Nash's concept of a warrior economy. ${ }^{27}$ Such economies are defined by their dependence upon pastoral farming at the expense of intensive arable farming. The strategy, Nash argues, is adopted because it does not require a large labour force during the periods when many men will be on campaign.

Attempts to estimate the size of the Batavian population and from this the impact of auxiliary recruitment upon the population reflect the creativity of the

\footnotetext{
${ }^{24}$ See Tacitus, Germania 29. This work, written $c$. AD 98-99, describes the arrangement as if it is still current. Though the comment could be an anachronism, other evidence suggests that it was not. Evidence that Batavian units continued to consist of Batavians after the revolt of AD 69 comes from diplomas. A partially published diploma found at Elst, a vicus within Batavian territory, was issued in AD 98 to a man who had served in a Batavian ala. This individual, who is recorded alongside his Batavian wife and children, must have been recruited $c$. AD 73 (M. M. Roxan, 'Veteran settlement of the auxilia in Germania' in G. Alföldy/B. Dobson/W. Eck, Kaiser, Heer und Gesellschaft in der römischen Kaiserzeit [Stuttgart 2000], 309). Another soldier, M. Ulpius Fronto, was discharged from cohors I Batavorum miliaria $c R$ in Upper Pannonia in AD 113 (M. M. Roxan, Roman Military Diplomas 1978-1984 [London 1985], no. 86). His diploma makes it quite clear that both he and his wife were Batavians. Continuity amongst commanding officers is implied by the name of Flavius Cerialis, prefect of cohors IX Batavorum at Vindolanda $c$. AD 100 (E. Birley, A.R. Birley and R. Birley, Vindolanda Reports. Volume II: The early wooden forts (Vindolanda 1993), 8-9) and by a second century tombstone recording a prefect of cohors III Batavorum (AE 1944, 97). The tombstone does not give the prefect's origin, but it does state that his wife came from the civitas capital of the Batavi, Ulpia Noviomagus.

${ }^{25} \mathrm{~N}$. Roymans, 'Romanisation and the transformation of a martial elite-ideology in a frontier province', in P. Brun/S. van der Leeuw/C. R. Whittaker (eds.), Frontières d'empire (Nemours 1993), 33-51.

${ }^{26}$ Willems 1984, op.cit. (n.22), 233-4.

${ }^{27}$ D. Nash, 'The basis of contact between Britain and Gaul in the Late Pre-Roman Iron Age', in S. Macready/F. Thompson (eds.), Cross-Channel Trade between Gaul and Britain in the Pre-Roman Iron Age (London 1984), 100-1.
} 
scholars who have produced them. Given that a reasonably accurate estimate is a necessary prerequisite for determining how far maintaining 5,500 or so men under arms affected the community as a whole, it is problematic that some approaches have worked from this figure and the assumption that it must have allowed 'socio-economic life to go on more or less undisturbed' ${ }^{28}$ It certainly seems unlikely that the Roman authorities would have entirely disregarded local, Batavian concerns, but the balance of power did not ultimately lie in the tribe's favour. Tacitus's account of dilectus that precipitated the Batavian revolt demonstrates that when confronted with a crisis, Roman power holders would put their strategic interests first. In this instance Tacitus does claim that such a dilectus was an innovation for the tribesmen, but there is nothing to prove that the manpower demands of the Roman state were not disruptive in other ways even in peacetime. Willems does, however, go on to offer a convincing and cautious survey of different estimates for the Batavian population in the first century $\mathrm{AD}$, concluding that it stood at 30,000 to 40,000 people in 4,000 to 6,000 households. $^{29}$ Keeping all the Batavian units serving Rome at establishment strength would, he observes, place considerable pressure on a population of this size. Roymans adds that 'it is probably no coincidence that it is among the Batavians that several cases are known of two brothers both serving in the army' and cites instances from both literature and epigraphy. ${ }^{30}$ He argues that almost every household must have had a soldier in the Roman army. It is hard to envisage a society more affected by auxiliary recruitment than the Batavi.

These conclusions alone underscore Roymans's argument that martiality was not only a defining element of Batavian life, it was also one underpinned by service with Rome. Roymans does, however, add further evidence to support his view - he notes that weapon deposition in rivers, and at holy sites such as Empel, continues from the Iron Age into the second century. ${ }^{31}$ This is despite the fact that the demilitarised tribes of the hinterland largely abandoned such practices after the Roman conquest.

Just how important the military role of the Batavian elite was in all this becomes evident when we look at Tacitus's account of the Civilis revolt. At the

\footnotetext{
${ }^{28}$ Willems 1984, op.cit. (n.22), 235.

${ }^{29}$ Willems 1984, op.cit. (n.22), 234-7.

${ }^{30}$ Roymans 1993, op.cit. (n.25), 40, n 27.

${ }^{31}$ Roymans 1993, op.cit. (n.25).
} 
time the dilectus is introduced, Batavian units, now including regular alae and cohortes are still under the command of native leaders. Tacitus emphasises the abuses that accompanied this innovation, but these may not have been the main cause of the Batavian leaders' frustration. The fact that outsiders, prefects and centurions abusive or otherwise, usurped their role may have led to serious loss of face in such a tribal community and threatened their position. ${ }^{32}$

For the Batavi, auxiliary recruitment was widely experienced throughout the community; indeed, it came to have very significant socio-economic implications. But these did not really facilitate what is conventionally understood as Romanisation. For example, we see little evidence for elite competition in the building of new urban centres; the attention of the aristocracy was focussed elsewhere. As Tacitus's portrait of Civilis ${ }^{33}$ and the archives of Cerialis at Vindolanda indicate Batavian officers could operate effectively within the new Roman-defined world order, but the development of this tribal society within the Empire was very strongly subordinated to larger regional concerns.

\section{Recruitment amongst the Ituraeans}

The Ituraeans occupied an extensive territory in the Roman period; Strabo writes that in his time they occupied the Lebanon and Anti-Lebanon ranges in addition to the valley of the Massyas, within which lay Chalcis and Heliopolis. ${ }^{34}$ Like the Batavians, they had a reputation amongst Romans as good fighters and had a long history of supplying troops for Rome's campaigns.

As their titles suggest at least two of the Ituraean units, ala I Augusta Ituraeorum and cohors I Augusta Ituraeorum, were most probably formed under Augustus. But even the cohorts that lacked this imperial title appear to have been in existence in the early Julio-Claudian period. Cohors II Ituraeorum equitata, for example, is attested in Egypt as early as AD $39 .{ }^{35}$ Kennedy (1989, 238) believes that the origin of some of the cohortes Ituraeorum may lie in the mercenary units that served Caesar, though this cannot be proven. Whenever

\footnotetext{
${ }^{32}$ Tacitus, Histories 4.14.

${ }^{33}$ Tacitus, Histories 4.12, 4.32.

${ }^{34}$ Strabo, Geography 16.2.10.

${ }^{35}$ ILS 8899 = CIL III 14147.
} 
they were founded, it is probably significant that none of these regiments is recorded as serving in its home province, and it seems highly likely that, as was the case with the second cohort, all were deployed overseas at an early date.

The combined strength of the regular regiments known to have been raised amongst the Ituraeans was not great; indeed, it may have amounted to little more than 3,000. ${ }^{36}$ As Dabrowa notes, ${ }^{37}$ this hardly constitutes a large group when compared to those of Gauls or Thracians, but in the context of Syria it represents one of the largest suppliers. Roman accounts of the region offer an explanation for this phenomenon: they consistently depict the Ituraeans as bandits. $^{38}$ The Ituraeans represent a stark contrast to the sedentary farming communities, appearing as a threat to agricultural development and a major security problem.

Fergus Millar's insightful comments on one such account bear repeating here. 'Strabo sees some relationship between raiding from the mountain (Mount Lebanon) to the plain and the coast and what he goes on to record, the foundation of a colonia at Berytus, with a territory stretching to the sources of the Orontes in the Bekaa valley'. ${ }^{39}$ Agrippa's decision to plant a colony at Berytus was to have far reaching implications both for the region in general and for the Ituraeans in particular. It essentially split their territory in half and handed legal title of a substantial part of it to veterans. Precisely what impact this had on the local population is unrecorded, but the Romans and their client rulers continued to regard the Ituraeans as a menace. The famous career inscription of Q. Aemilius Secundus refers to operations against the Ituraeans in this region a couple of decades after the foundation of the Berytus colonia.$^{40}$ Judging from parallels elsewhere in the Empire, such as the ongoing recruitment of soldiers from the bandit-plagued Haemus Mountains of Thracia, the Roman authorities may well have sought to stabilise the area by conscripting potentially unruly elements. ${ }^{41}$ It seems highly probable that, as

\footnotetext{
${ }^{36}$ This certainly seems small in comparison with the population of one known city, Apamea. The Aemilius Secundus inscription also tells us that the census of AD 6 counted 117,000 persons (ILS 2683).

${ }^{37}$ E. Dabrowa, 'Cohortes Ituraeorum', Zeitschrift für papyrologische Urkunden 63 (1986), 230.

${ }^{38}$ In addition to Strabo, Cicero (Philippica. 2.44.112) and Flavius Josephus (Antiquities 15. 10.1, 16.9.1) refer to the Ituraeans.

${ }^{39}$ F. Millar, The Roman Near East (Harvard 1993), 36 on Strabo, Geography 16.2.18-9.

${ }^{40}$ ILS 2683.

${ }^{41}$ For the link between the Haemus mountains, brigands and recruitment see Apuleius, Metamorphoses 7.4-6.
} 
Shürer suggests, several of the Ituraean units were therefore formed during or after Augustan pacification campaigns in the area. ${ }^{42}$

There is a marked transformation in this part of the Near East during the Roman period characterised by the spread of sedentary peoples. ${ }^{43}$ Behind this process lay various interventions by the Roman state and its clients; the establishment of military colonies is perhaps the best known, but others such as legislation, cadastration and the building of dams have been suggested. ${ }^{44}$ But alongside these, contributing to this transformation, was the forced migration, as soldiers of Rome, of those considered bandits or potential bandits.

I have argued elsewhere that military service could have had a major impact on the cultural identity of auxiliary soldiers, irrespective of whether they were volunteers or conscripts. ${ }^{45}$ The knowledge acquired in the course of military service and perhaps the money saved following a career with a regular pay packet must have benefited many veterans seeking to make their way in provincial society. We might even reasonably expect to find such men amongst leading figures in local communities, patrons and politicians playing a key role in the transformation of public life, but in fact there is remarkably little evidence for them serving in these capacities - why?

\section{Veteran Settlement}

Before addressing this important question, it is appropriate to pause and reflect for a moment on welcome developments in the study of auxiliary veteran settlement. I think here particularly of papers in the volume Heer und Integrationspolitik, edited by Professors Eck and Wolff, and of Margaret Roxan's long-term project investigating settlement of veterans during the first

\footnotetext{
${ }^{42}$ E. Shürer, The History of the Jewish People in the Age of Jesus Christ (Edinburgh 1973), 570.

${ }^{43}$ A. H. M. Jones, 'The Urbanization of the Ituraean Principality', Journal of Roman Studies 21 (1931), 265-75; E. Frézouls, 'Cyrrhus et Cyrrhestique jusqu'à la fin du Haut-Empire', Aufstieg und Niedergang der Römischen Welt 2.8 (1977), 164-97; G. Tate, 'The Syrian countryside during the Roman Era' in S. Alcock, (ed.), The Early Roman Empire in the East (Oxford 1997), 55.

${ }^{44}$ Tate 1997, op.cit. (n.43), 60.

${ }^{45}$ I. P. Haynes, 'Military service and cultural identity in the auxilia', in A.Goldsworthy/I. P.Haynes (eds.), The Roman Army as a Community, Journal of Roman Archaeology Supp ser 34 (Ann Arbor 1999), 165-74.
} 
two and a half centuries AD. So far she has tackled Britain, Pannonia and Germania. ${ }^{46}$

Amongst the many informative papers in Heer und Integrationspolitik, it is useful to recall Kellner's attempt to draw conclusions from the finds statistics we now have for military diplomas. ${ }^{47}$ Kellner's approach is a valuable one, and scholars will do well to return to it repeatedly as more diplomas are discovered, but at the present time it also reveals the limitations of such analytical strategies: when the number of diplomas with known find-spots is broken down both chronologically and geographically, the samples left are too small to be considered statistically significant. ${ }^{48}$ Our data is also at the mercy of a large number of ill-understood variables, the $\mathrm{N}$ and $\mathrm{C}$ transforms so important in archaeology. It has been widely observed that the recovery of known diplomas owes little to the frequency of excavation in a given area, and most likely more to the contemporary cultural factors. How else may we explain, for example, the fact that almost three times as many diplomas are known from Mauretania Tingitana than Britain? Kellner usefully suggests, for example, that metal diplomas were more important acquisitions in provinces where the population consisted predominantly of peregrini, than in those cases where Roman citizens predominated. ${ }^{49}$ But, particularly when seeking to identify distribution patterns within provinces, it is clear that other factors can also influence find spots..$^{50}$ The discovery of a diploma in a particular place does not necessarily indicate that a veteran once lived there. It may also be useful here to emphasise the distinction between find-spot and archaeological context. It is one thing to know, down say to $5 \mathrm{~m}$ accuracy, where a diploma was found, it is quite another to know the detailed archaeological evidence for its deposition.

46 W. Eck/H. Wolff, (eds.), Heer und Intergrationspolitik. Die römischen Militärdiplome als historische Quelle (Passau 1986); for Britain and Pannonia see M. M. Roxan, 'Settlement of veterans of the auxilia - a preliminary study' in W. Groenman-van Waateringe, B. L. van Beek, W. J. H. Willems and S. L. Wynia (eds.), Roman Frontier Studies 1995 (Oxford 1995), 483-491; for Germany see Roxan 2000, op.cit. (n.24), 307-320.

${ }^{47}$ H.-J. Kellner, 'Die Möglichkeit von Rückschlüssen aus der Fundstatistik', in Eck/Wolff 1986, op.cit. (n.46), 241-8.

${ }^{48}$ Kellner's total sample of auxiliary diplomas where both the holder's original garrison location and the diplomas find-spot are known amounts to 217 examples (1986, op.cit. (n.47), 242). The largest number of diplomas with known find-spots from individual provinces are 32 from Raetia and 31 from Mauretania Tingitana (ibid. 244). It soon becomes apparent that, when sub-divided into chronological ranges, these groups are too small to permit meaningful statistical analysis.

${ }^{49}$ Kellner 1986, op.cit. (n.47), 245.

${ }^{50} \mathrm{See}$, for example, M. M. Roxan, 'Findspots of Military Diplomas of the Roman Auxiliary Army', University College London Institute of Archaeology Bulletin 26 (1989), 127-81. 
Roxan's long-term project will certainly help us to understand variation in the use of diplomas. Clearly, however, it will be difficult to offer a wider yet more detailed picture until her province-based studies are complete.

Kellner's observation that a majority of veterans appear to have settled near the frontier rather than in the hinterland lends support to the view that a high proportion of families living in settlements on the peripheries of the Empire had military ties. ${ }^{51}$ It also fits well with the emergence of a partly selfsustaining military community. This then may be one aspect of the impact of veteran settlement, but it also, ironically, suggests that the contribution of veterans to the transformation of provincial cultures was ultimately rather restricted. If military men continued to settle in proximity to one another, an arrangement many might have found advantageous, their impact would be highly concentrated not widely diffused..$^{52}$

This may go someway to explaining why auxiliary veterans do not appear to have played a significant role in municipal government, but there other factors too which need to be considered. If we look at Mrozewicz's comprehensive study of veterans in the Rhine and Danube provinces, only about $5.8 \%$ of all known municipal office holders were veterans of any sort..$^{33}$ The overwhelming majority of these served in the legions and about half of the total were officers; few got beyond membership of the town council. This clearly does not indicate that veterans as a group played a disproportionately large role in provincial administration. ${ }^{54}$ Elsewhere participation rates were even lower, in Britain, for

\footnotetext{
${ }^{51}$ Kellner 1986, op.cit. (n.47), 243.

52 A classic example of this phenomenon at a local level comes from Intercisa in Pannonia. Twenty-three inscriptions recording veterans of the cohors I Hemesenorum were found at this site, close to their former regiment's base. The evidence indicates the importance of family ties and ethnic bonds to the veterans (Roxan 2000, op.cit. [n.24], 308). Many decided to stay rather than move away, thus creating what Alföldy describes as a classic Militärgesellschaft (G. Alföldy, 'Das Heer in der Sozialstruktur des römischen Kaiserreiches', in: G. Alföldy/B.Dobson/W. Eck, (eds.), Kaiser, Heer und Gesellschaft in der römischen Kaiserzeit (Stuttgart 2000), 49.

${ }^{53}$ L. Mroszewicz, 'Die Veteranen in den Munizipalräten an Rhein und Donau zur hohen Kaiserzeit (1.-3. Jh.)', Eos 77 (1989), $71 \mathrm{ff}$. See also the excellent evaluation of veterans' participation in public life in G. Wesch-Klein, Sozialaspekte des römischen Heerwesens in der Kaiserzeit (Stuttgart 1998), 196-7.

${ }^{54}$ See also Wesch-Klein1998, op.cit. (n.53), 196. F. Mitthof, 'Soldaten und Veteranen in der Gessellschaft des römischen Ägypten (1.-2.Jh. n. Chr.)' in: G. Alföldy/B. Dobson/W. Eck, (eds.), Kaiser, Heer und Gesellschaft in der römischen Kaiserzeit (Stuttgart 2000), 378 argues that military families comprised 3$5 \%$ of total population of Roman Egypt.
} 
example, there are no examples of veterans reaching the ordo decurionum. ${ }^{55}$ It is possible that in at least some cases low levels of participation reflect deliberate choices made by veterans rather than lack of opportunity. An Egyptian papyrus dated just prior to the battle of Actium records Octavian's statement that veterans were not to be appointed against their will to magistracies, or to the role of ambassadors or tax farmers. ${ }^{56}$ If such immunities operated in later periods it is highly likely that many ex-soldiers would wish to exploit them.

If, for whatever reason, veterans of all categories did not as a group represent a major force in town government, it is worth noting that former auxiliaries hardly appear at all. Indeed, there is no known example of an auxiliary miles or eques, as distinct from an officer, becoming a town decurion anywhere in the north-western provinces or indeed in Dacia. ${ }^{57}$ It is not that they were barred from performing this role; we know that a few men did reach such positions elsewhere. Gaius Julius Dexter, for example, who began his career as a trooper in an ala, became a duovir in the colony of Thelepte (Medinet-el-Kedima, Tunisia) in the second century. ${ }^{58}$ But even in this case, the man had risen in the ranks before he retired from the army. Nor can the low representation of auxiliary veterans, compared even to the ex-milites of the legions, be explained by any lack of familiarity with Roman culture on the part of the former.

The current scholarly consensus holds that legionaries and auxiliaries received significantly different privileges and awards. ${ }^{59}$ If this view is correct, it may account for the under-representation of auxiliary veterans in government. ${ }^{60}$ Most commonly cited is the land grant, or its monetary equivalent, awarded on discharge. We know that this was awarded to legionaries from the time of

\footnotetext{
${ }^{55}$ Wesch-Klein 1998, op.cit. (n.53), 197.

${ }^{56}$ BGU 628 = FIRA 1.56.

${ }^{57}$ For north-western provinces see Wesch-Klein 1998, op.cit. (n.51), 197. For Dacia see R. Ardevan, 'Veteranen und städtische Dekurionen in römischen Dakien', Eos 77 (1989), 85-6.

${ }^{58}$ CIL VIII $2094=$ ILS 2518.

${ }^{59}$ R. Alston, 'Roman Military Pay from Caesar to Diocletian', Journal of Roman Studies 84 (1994), 113 a lone voice, challenges this broad consensus on the question of pay, arguing that the assumption that troop categories were treated differently owes much to 'reasons central to much of Roman imperial military historiography'. He performs a great service in reminding students of the Roman army of the danger of drawing too many parallels between modern and ancient armies. If correct, his argument could equally apply to other ill-understood aspects of Roman military life such as length of service and the award of donatives. My own views on each of these points follow in the text.

${ }^{60}$ See also Wesch-Klein 1998, op.cit. (n.53), 197 who argues that auxiliary soldiers probably did not have the financial means to acquire a town decurion's post.
} 
Augustus. There is, however, no evidence that auxiliary veterans received the same benefits and indeed there is broad scholarly agreement that they did not. ${ }^{61}$ Evaluation of the evidence is complicated somewhat by the use of the general term milites in the ancient sources. ${ }^{62}$ This term could, of course, be applied equally to legionaries and auxiliaries. This gratuity or grant, valued at 3,000 denarii under Augustus, ${ }^{63}$ would have been an enormous help to a former soldier beginning civilian life. If as is commonly held, this award was extended only to legionaries, we may see some explanation for their greater representation amongst municipal office holders. Whether or not this was the case, however, there is other evidence to suggest that legionary veterans were generally wealthier than their auxiliary counterparts.

Another factor that must be considered is savings. These would vary from soldier to soldier, and some auxiliaries, such as Dionysius of the ala veterana Gallica, could amass sizeable sums, ${ }^{64}$ but overall legionaries could probably save more. Watson suggests that the Severan pay records of one auxiliary cohort, in which the consistent majority of soldiers had the sums of 100 denarii in deposito and 75 denarii in viatico, indicate that the amount such soldiers could save was officially restricted ${ }^{65}$ Restrictions on legionary savings are known, of course, for example Domitian's restrictions in the aftermath of the revolt of Antoninus Saturninus, but legionaries most probably received higher salaries from which to save. ${ }^{66}$ It is also possible that auxiliaries were not entitled to receive donatives, ${ }^{67}$ though again there is no unambiguous evidence that they were not.

Benefits received on discharge varied depending upon the type of unit in which a soldier served. Evidence for such distinctions may be found in a papyrus of $\mathrm{AD} 63$ which records a decision made by the Prefect of Egypt. The prefect was

${ }^{61}$ See G. R. Watson, 'Discharge and resettlement in the Roman army. The praemia militiae', in E. C. Welskopf, (ed.), Neue Beiträge zur Geschichte der alten Welt. Band II. (Berlin 1965), 152. Watson responds to reservations expressed in P. A. Brunt, 'Pay and Superannuation in the Roman army', Proceedings of the British School at Rome, New series 5, 55ff.

${ }^{62}$ I am most grateful to Michael Alexander Speidel for alerting me to this point.

${ }^{63}$ Cassius Dio 55.23.

${ }^{64}$ At one stage Dionysius had 1,562 denarii in his savings (P. Fay. 105.2.28 and 105.2.44).

${ }^{65}$ Watson 1965, op.cit. (n.61), 153; P. Berlin 6866.

${ }^{66}$ For the revolt of Saturninus see Suetonius, Domitian 7. Concerning pay differences I follow M. A. Speidel, Die römischen Schreibtafeln von Vindonissa (Vindonissa 1996), 64-6 contra Alston 1994, op.cit. (n.59) here.

${ }^{67}$ Cheesman 1914, op.cit. (n.4), 34-5; A. von Domaszewski, 'Der Truppensold der Kaiserzeit', Neue Heidelberger Jahrbücher 10 (1900), 226; Domaszewski 1907, op.cit. (n.5), 68. 
approached by a mixed group of veterans, some from the legions, some from alae, some from cohorts and others from the fleet, but he emphasised that each category should be treated separately ${ }^{68}$ Epigraphic evidence may also reflect this difference. I note, for example, that veterans' tombstones in Britain either state that the veteran is from a legion or they just refer to him as a veteran. There are no examples where the deceased is referred to explicitly as an auxiliary veteran. ${ }^{69}$ Is this because legionary veterans wish to emphasise their higher status, while auxiliary veterans generally prefer not to underscore their lower standing?

Finally, one further factor may have counted against auxiliary veterans who might have otherwise been inclined to compete for office against legionary veterans and civilians. This was age. All soldiers were disadvantaged compared to civilians not only because if they took civil office at all, they did so later in life, but also because once they were discharged they had a shorter life expectancy than their civilian contemporaries. As Burn notes, of men alive at 42 who served in the army at Lambaesis, half had died by $57 .^{70}$ This contrasts with civilians in the same age group and from the same area, half of whom reached 69. A similar comparison for the Danube region suggests a difference there too, with half of those soldiers who survived to 42 living onto 58 as opposed to 60 for civilians. If, as is commonly argued, auxiliary soldiers normally served five years longer, and thus retired on average 5 years later, than their legionary counterparts, this might be a further explanation for their poor showing in records of civil office holders.

If auxiliary veterans were disadvantaged in some or all of the ways outlined above, it would certainly explain why the only auxiliaries who did become involved in local government had normally reached the rank of centurion or decurion prior to their discharge. Such men are represented by a former decurion in the ala II Pannoniorum, who subsequently served as decurion in colonia Dacica Sarmizegetusa, municipium Napoca and the canabae of Legio XIII in Apulum, Dacia and Ti. Iulius Bellicus, decurion in ala II Asturum, who

\footnotetext{
${ }^{68}$ FIRA 3.171.

${ }^{69} \mathrm{Six}$ RIB entries refer to individuals styled simply veteranus $(358,517,534,770 \& 887)$, three of these are from sites with legionary bases, the remaining inscriptions make explicit reference to former legionary veterans - veteranus ex legione $(249,252,478)$ and veteranus legionis $(359,361,363,495,500,679,685)$.

${ }^{70}$ A. R. Burn, 'Hic breve vivitur', Past and Present 4 (1953), 16.
} 
became decurion in the municipium of Celeia (Celje) Noricum.." Similarly when auxiliary veterans are found within colonia, performing acts of evergetism, they tend to come from these ranks or at least from higher status units. For example, we find T. Flavius Quir. Breucus of the ala I Pannoniorum making a dedication to the Genius of the colony of Cuicul (Djemila). ${ }^{72}$ Such examples reinforce the impression that the average cohort veteran would have been less able to compete in the public sphere with his former superiors or wealthier contemporaries from the legions.

It is, of course, entirely possible to envisage former auxiliary soldiers having an impact on provincial society without being a member of local government. The authorities might have decided to settle such men in key areas as a security measure hoping to bring difficult areas under control. Gerov, for example, seeks to explain a concentration of inscriptions recording individuals whose citizenship was awarded under the Flavians as evidence for deliberate settlement of auxiliary veterans at Cerna Gora on the road to the ancient city of Hadrianopolis, Bulgaria. ${ }^{73} \mathrm{I}$ have been able to find only one instance in the entire Empire where an auxiliary veteran is explicitly described as settled by deductio, ${ }^{74}$ however, and in this instance it appears to be the exception that proves the rule. For the example concerns a soldier who served in a unit levied from Roman citizens and accorded the special service conditions otherwise specific to legionaries. ${ }^{75}$

Alternatively we may imagine that veterans could be influential figures at village level or act as prosperous 'gentlemen farmers', but what do our sources actually tell us? Tacitus mentions Cruptorix, an auxiliary veteran farmer, as an

\footnotetext{
${ }^{71}$ Dacia, CIL III 1100 = ILS 71410; Noricum, CIL III 15205, 3. Many auxiliary centurions and decurions may not have worked there way up through the ranks anyway. In several instances it appears that they came from leading provincial families themselves. In such circumstances their participation in local government is less a benefit of social mobility acquired through the army and more continuation of the family's role. One example of a likely direct appointment to the centurionate is $\mathrm{C}$. Iul. Sabinus, centurion in cohors II Raetorum $c$ R. He died at 25 , far too young surely to have worked his way up through the ranks. His father C. Iul. C. f. Clemens shown on the same tombstone wearing a toga and is described as a veteran from colony of Forum Iulii (Fréjus) in Narbonese Gaul (CIL XIII 7583). Sabinus's service was cut short by his early death, but it is not difficult to imagine him planning a public career.

${ }^{72}$ AE 1915, 69 and AE 1992, 1884.

${ }^{73}$ B. Gerov, Landownership in Roman Thracia and Moesia (Amsterdam 1988), 63.

${ }^{74}$ CIL X 6672.

${ }^{75}$ M. Mirkovic, 'Military diplomas from Viminacium and the settlement of auxiliary veterans: city or countryside?' in: G. Alfoldy/B. Dobson/W. Eck (eds.), Kaiser, Heer und Gesellschaft in der römischen Kaiserzeit (Stuttgart 2000), 370.
} 
aside in his account of the Frisian Revolt of $\mathrm{AD} 47,{ }^{76}$ but we have little real evidence apart from this case. Indeed even for legionary veterans the material attesting to non-government activities is scant. ${ }^{77}$ In what follows, I would like to evaluate evidence for former soldiers in village communities, drawing first on Egyptian papyri and secondly on inscriptions from Syria.

\section{Veterans in Roman Egypt}

When examining the Egyptian evidence it is important to recognise that the key developments in village administration in the Roman period took place before extensive veteran settlement. The agents in this change came not from exsoldiers, but from a well-established pool of local leaders. At Philadelphia, a village that began to attract a significant number of veterans from the mid $A D$ 80 s, for example, Hanson has demonstrated that administrative change was well underway, in or by the reigns of Claudius and Nero. ${ }^{78}$

As always, it is vital to ask how far evidence from Egypt may be applied to other regions of the Empire. Communities with a long tradition of using writing in local administration would be well supplied with indigenous civilians with the skills to operate Roman administration. In other provinces, where such a tradition was absent or less well developed, literate veterans may have had much more of an impact.

Both Alston and Mitthof offer useful studies of the role of soldiers and veterans in village society based on the Egyptian evidence. ${ }^{79}$ Both emphasise that veterans were thoroughly integrated with the general civilian population, that they did not constitute a separate caste and did not have a significant impact on the cultural life of their villages. In some cases, rather than being exotic outsiders these men were simply returning to the place in which they grew up before their military careers. Furthermore, Alston emphasises that numerically

\footnotetext{
76 Tacitus, Annals 4.73 .

${ }^{77}$ See Wesch-Klein 1998, op.cit. (n.53), 195-6 for a useful summary.

${ }^{78}$ Hanson discusses papers from the archive of Nemesion, collector of capitation taxes at Philadelphia. She observes that the documents note the begining of the Roman year and that the tax office followed a quinquennial cycle when revising lists of the villagers' ages (A. E. Hanson, 'Village officials at Philadelphia: a model of Romanization in the Julio-Claudian period', in L. Criscuolo/G. Geraci (eds.) Egitto e storia antica dall' ellenismo all' età araba (Bologna1989), 439.

${ }^{79}$ Alston 1995, op.cit. (n.2), 117-42; R. Alston, 'The ties that bind: soldiers and societies' in A. Goldsworthy/I. P. Haynes (eds.), The Roman Army as a Community, Journal of Roman Archaeology Supp ser 34 (Ann Arbor 1999), 175-96; Mitthof 2000, op.cit. (n.54), 377-405.
} 
veterans and those of their children that shared their rights as veterans still represented a very small group, less than $1 \%$ of the total population of Egypt. ${ }^{80}$ Even in those villages where a higher proportion of the population was composed of veterans, such as Karanis, where perhaps as many as $14 \%$ of the inhabitants were from families with military links, the impact was gradual and spread over several generations, rather than dramatic. ${ }^{81}$ Though far from constituting a powerful caste, these individuals gained tangible benefits from their citizenship, enabling them to establish themselves in the land-owning class even if not to play a leading role in local politics. ${ }^{82}$ Moreover, they do appear to be represented disproportionately strongly amongst the wealthier members of the village. ${ }^{83}$ Finally, of course, these families enjoyed some social mobility, succeeding generations could exploit opportunities unavailable to their parents. For the legitimate sons of discharged auxiliaries, for example, service in the legions was now an option their fathers might never have had.

\section{Veterans in Roman Syria}

In Syria, away from the long-established urban centres, veterans appear to have had a far more conspicuous impact within some communities. The most notable examples of this phenomenon appear within the Ituraean principality, an area that changed quite dramatically during the Roman period. ${ }^{84}$ Here veterans are found undertaking a host of roles at village level. These men appear heading subscription lists, in magistracies, as benefactors and founders of villages and as tribal patrons. ${ }^{85}$ All these roles emulate those performed in the larger and better-attested towns of the Near East, and many would have been undertaken across the Empire, but it is rare to find them so richly attested at village level.

\footnotetext{
${ }^{80}$ Alston 1995, op.cit. (n.2), 51.

${ }^{81}$ According to Alston 1995, op.cit. (n.2), 123, 14\% of the individuals recorded on the tax lists for Karanis had Roman names. As Alston emphasizes repeatedly in his work, names can be misleading. He suggests reasonably enough, however, that while not all of those with Roman names would have been veterans, a high proportion would have either seen military service or have been related to someone who had.

${ }^{82}$ Mitthof 2000, op.cit. (n.54), 401.

${ }^{83} \mathrm{H}$. Geremek, Karanis: Communité rurale de l'Egypte romaine au IIe-IIIe siècles de notre ère, (Warsaw 1969), 56-7.

${ }^{84}$ Jones 1931, op.cit. (n.43), 271.

${ }^{85}$ Village subscription list (Wadd. 2399), village magistracies (Wadd. 1969, 1984b, 1989, 2041, 2546), 'benefactor and founder' (Wadd. 2413), tribal patron (Wadd. 2287).
} 
Interestingly, only one of the veterans, a centurion of Legio III Gallica, records his former rank and unit. $\mathrm{He}$ is, however, exceptional, a man capable of erecting a public building at his own expense. ${ }^{86}$ The remaining veterans, most probably both legionaries and auxiliaries, undertake less expensive public service more appropriate to their former status; nevertheless they too appear to enjoy a high position in local society. ${ }^{87}$ Their influence contrasts vividly with that of their Egyptian counterparts.

The differing impact of the Egyptian and the Syrian veterans is instructive. In Egypt the social networks and the administrative structures of the villages are well established before veterans begin to settle in large numbers. Most of the ex-soldiers are able to live comfortably within the village community, but none of them appears to be dramatically wealthier than the established farmers whom they settle alongside. In the Ituraean principality, however, the situation is very different. Pacification and urbanisation of the region transforms the settlement pattern during the Roman period. New areas are brought under the plough. Farming communities emerge where none previously existed. This transformation offers new opportunities for men with some money and an understanding of the wider workings of the imperial state. A former soldier can found a village or become a patron to a tribe. It is a scenario most probably repeated in many provinces, but only here does the evidence survive at village level to demonstrate the vital role veterans performed.

\section{Conclusion}

Attempts to assess the impact of auxiliary recruitment upon provincial societies are fraught with difficulties. Before arguing that the phenomenon was profoundly significant, it is vital to place it within its wider context. Auxiliary units were not raised evenly across the Empire, and auxiliary recruits were supplied in widely varying numbers from one place to another. The picture that emerges is therefore one of significant regional variation. It is possible to investigate further this regional variation only when a fairly complete picture of local settlement and demographic structure is available. At present this is possible only for a small proportion of provinces.

Much the same evidence is vital if one is to assess the role of auxiliary veteran

\footnotetext{
${ }^{86}$ Wadd. 2438.

${ }^{87}$ See Jones 1931 , op.cit. (n.43), 270 for this analysis of the epigraphic material.
} 
settlement in the transformation of local societies. In some communities, the veterans do not appear to have had a dramatic impact; in others they seem to be key drivers of social change. When discussing veterans, there are, however, further complications. Despite much scholarly discussion, there is real uncertainty over the extent to which auxiliaries were treated differently to their legionary counterparts. This presents significant problems when trying to assess the reasons for the two groups' different profiles in provincial society and offers much further scope for future research.

London, July 2000 